\title{
Human prion diseases: surgical lessons learned from iatrogenic prion transmission
}

\author{
David J. Bonda, MD, ${ }^{1}$ Sunil Manjila, MD, ${ }^{1}$ Prachi Mehndiratta, MD, ${ }^{2}$ Fahd Khan, MD, ${ }^{3}$ \\ Benjamin R. Miller, MD, ${ }^{1}$ Kaine Onwuzulike, MD, ${ }^{1}$ Gianfranco Puoti, MD, PhD, ${ }^{4}$ \\ Mark L. Cohen, MD, ${ }^{5,6}$ Lawrence B. Schonberger, MD, MPH, ${ }^{7}$ and Ignazio Cali, PhD ${ }^{4,6}$
}

\begin{abstract}
${ }^{1}$ Department of Neurological Surgery, University Hospitals Case Medical Center, and ${ }^{5}$ National Prion Disease Pathology Surveillance Center, ${ }^{6}$ Department of Pathology, Case Western Reserve University School of Medicine, Cleveland, Ohio; 2Department of Neurology, University of Virginia Health System, Charlottesville, Virginia; ${ }^{3}$ Department of Neurosurgery, Stanford University, Stanford, California; " Department of Clinical and Experimental Medicine, Second University of Naples, Naples, Italy; and 'Division of High-Consequence Pathogens and Pathology, National Center for Emerging and Zoonotic Infectious Diseases, Centers for Disease Control and Prevention, Atlanta, Georgia
\end{abstract}

The human prion diseases, or transmissible spongiform encephalopathies, have captivated our imaginations since their discovery in the Fore linguistic group in Papua New Guinea in the 1950s. The mysterious and poorly understood "infectious protein" has become somewhat of a household name in many regions across the globe. From bovine spongiform encephalopathy (BSE), commonly identified as mad cow disease, to endocannibalism, media outlets have capitalized on these devastatingly fatal neurological conditions. Interestingly, since their discovery, there have been more than 492 incidents of iatrogenic transmission of prion diseases, largely resulting from prion-contaminated growth hormone and dura mater grafts. Although fewer than 9 cases of probable iatrogenic neurosurgical cases of Creutzfeldt-Jakob disease (CJD) have been reported worldwide, the likelihood of some missed cases and the potential for prion transmission by neurosurgery create considerable concern. Laboratory studies indicate that standard decontamination and sterilization procedures may be insufficient to completely remove infectivity from prion-contaminated instruments. In this unfortunate event, the instruments may transmit the prion disease to others. Much caution therefore should be taken in the absence of strong evidence against the presence of a prion disease in a neurosurgical patient. While the Centers for Disease Control and Prevention (CDC) and World Health Organization (WHO) have devised risk assessment and decontamination protocols for the prevention of iatrogenic transmission of the prion diseases, incidents of possible exposure to prions have unfortunately occurred in the United States. In this article, the authors outline the historical discoveries that led from kuru to the identification and isolation of the pathological prion proteins in addition to providing a brief description of human prion diseases and iatrogenic forms of CJD, a brief history of prion disease nosocomial transmission, and a summary of the CDC and WHO guidelines for prevention of prion disease transmission and decontamination of prioncontaminated neurosurgical instruments.

http://thejns.org/doi/abs/10.3171/2016.5.FOCUS15126

KEY WORDS scrapie prion protein; transmissible spongiform encephalopathy; iatrogenic; neurosurgery; instrument decontamination

$\mathrm{T}$ HE human prion diseases are a rare group of uniformly fatal neurodegenerative disorders characterized by a rapid decline in cognition and movement with features of cerebral and cerebellar dysfunction. ${ }^{37,55,79}$ Although they differ in their specific clinical and pathological manifestations (Table 1), the prion diseases have in common the accumulation of small, highly resilient proteins traditionally known as prions, which are capable of self-propagation via autocatalytic templating activity.,35 Prions have been demonstrated to be resistant to conventional methods of decontamination. ${ }^{88}$ The presence of prion-contaminated instruments in the operating room can pose a serious risk to health care providers and patients., ${ }^{3,11}$ In the absence of strong evidence against a prion disease diagnosis in a neurosurgical patient, cautionary measures should be taken to prevent iatrogenic transmission of pri-

ABBREVIATIONS BSE = bovine spongiform encephalopathy; CDC = Centers for Disease Control and Prevention; CJD = Creutzfeldt-Jakob disease; $d C J D=C J D$ transmitted by commercially distributed cadaveric dura mater; EEG = electroencephalography; fCJD = familial CJD; FFI = fatal familial insomnia; GSS = Gerstmann-SchäusslerScheinker syndrome; $\mathrm{hGH}=$ human growth hormone; iCJD = iatrogenic CJD: $\mathrm{M}=$ methionine; $\mathrm{NIH}=$ National Institutes of Health; PrP = prion protein; PrPc = cellular PrP; $\mathrm{PrPsc}=$ abnormal form of PrP; sCJD = sporadic CJD; sFI = sporadic fatal insomnia; $\mathrm{V}=$ valine; $\mathrm{vCJD}=$ variant CJD; VPSPr = variably protease-sensitive prionopathy; WHO $=$ World Health Organization.

SUBMITTED March 4, 2015. ACCEPTED May 18, 2016.

INCLUDE WHEN CITING DOI: 10.3171/2016.5.FOCUS15126. 
TABLE 1. Clinical and histopathological features of the human prion diseases

\begin{tabular}{|c|c|c|c|c|}
\hline $\begin{array}{l}\text { Etiology \& } \\
\text { Disease }\end{array}$ & $\begin{array}{c}\text { Age at Onset } \\
\text { (yrs) }\end{array}$ & $\begin{array}{l}\text { Disease Duration } \\
\text { (mos) }\end{array}$ & $\begin{array}{c}\text { Presenting Clinical } \\
\text { Sx/Signs }\end{array}$ & Neuropathology \\
\hline \multicolumn{5}{|l|}{ Acquired } \\
\hline $\begin{array}{l}\text { latrogenic* } \\
\text { CJD }\end{array}$ & $\begin{array}{l}\text { Mean } 58, \text { SD } 15, \\
\text { range } 26-76^{92}\end{array}$ & Mean 15.8, SD $9.2^{68}$ & $\begin{array}{l}\text { Typically w/ gait abnormalities \& } \\
\text { ataxia }\end{array}$ & $\begin{array}{l}\text { Spongiform degen, gliosis, neuronal loss; } \sim 68 \% \\
\text { of cases show amyloid plaques }\end{array}$ \\
\hline $\begin{array}{r}\text { Variant } \\
\text { CJD }\end{array}$ & Median $26^{83}$ & Median 14, range $6-39^{81}$ & $\begin{array}{l}\text { Psychiatric/behavioral Sx, paresthe- } \\
\text { sia or dysthesia, delayed devel- } \\
\text { opment of neurological signs }\end{array}$ & $\begin{array}{l}\text { Numerous amyloid plaques surrounded by } \\
\text { vacuoles ("florid plaques"), spongiform degen } \\
\text { most evident in basal ganglia \& thalamus }\end{array}$ \\
\hline Kuru & $\begin{array}{l}\text { Range } \sim 5 \text { to } \\
>50^{24,89}\end{array}$ & Range $\sim 3-36^{89}$ & $\begin{array}{l}\text { Progressive cerebellar ataxia, no } \\
\text { cognitive change }\end{array}$ & $\begin{array}{l}\text { Kuru plaques† (greatest frequency in cerebel- } \\
\text { lum), neuronal loss, \& astrocyte hypertrophy }\end{array}$ \\
\hline \multicolumn{5}{|l|}{ Inherited } \\
\hline $\begin{array}{l}\text { Familial } \\
\text { CJD } \ddagger\end{array}$ & $\begin{array}{l}\text { Mean } 58, \text { range } \\
35-66^{37}\end{array}$ & Mean 6, range $2-41^{37}$ & $\begin{array}{l}\text { Dementia, psychiatric changes \& } \\
\text { ataxia; myoclonus; rarely gaze } \\
\text { palsies \& neuropathy }\end{array}$ & $\begin{array}{l}\text { Spongiform degen, gliosis, \& neuronal loss w/ } \\
\text { severity as function of disease duration }\end{array}$ \\
\hline $\mathrm{FFI}$ & $\begin{array}{l}\text { Mean } 49 \text {, range } \\
20-71^{37}\end{array}$ & $\begin{array}{l}\text { Mean } 11, \text { SD } 4 \text { in } 129 \mathrm{M} / \mathrm{M} ; \\
\text { mean, } 23, \text { SD } 19 \text { in } 129 \\
\mathrm{M} / \mathrm{V} ; \text { range } 6-33^{37}\end{array}$ & $\begin{array}{l}\text { Sleep disturbances \& autonomic } \\
\text { dysfunction }\end{array}$ & $\begin{array}{l}\text { Neuronal loss \& mild gliosis (predominantly in } \\
\text { thalamus), rare spongiform degen or plaques }\end{array}$ \\
\hline GSS§ & Range $30-62^{55}$ & Range $1-120^{55}$ & $\begin{array}{l}\text { Cerebellar abnormalities, dysthe- } \\
\text { sia, hyporeflexia, proximal leg } \\
\text { weakness }\end{array}$ & $\begin{array}{l}\text { Variable; spongiform degen, gliosis, \& kuru } \\
\text { plaques vary in location \& severity, neurofi- } \\
\text { brillary tangles also evident }\end{array}$ \\
\hline \multicolumn{5}{|l|}{ Sporadic } \\
\hline $\begin{array}{l}\text { Sporadic } \\
\text { CJD }\end{array}$ & $\begin{array}{l}\text { Mean } 64,,^{79} \text { range } \\
19-91^{55}\end{array}$ & Mean $8,{ }^{79}$ range $1-72^{55}$ & $\begin{array}{l}\text { Dementia, myoclonus, cerebellar } \\
\text { dysfunction }\end{array}$ & $\begin{array}{l}\text { Spongiform degen, gliosis, neuronal loss; amy- } \\
\text { loid plaques in SCJD-MV2 subtype }\end{array}$ \\
\hline $\begin{array}{l}\text { Sporadic } \\
\text { FI }\end{array}$ & $\begin{array}{l}\text { Median } 46,{ }^{79} \\
\text { SD13, }{ }^{79} \text { range } \\
24-74^{55}\end{array}$ & $\begin{array}{l}\text { Median } 24,{ }^{79} \mathrm{SD} 13,,^{79} \\
\quad \text { range } 10-73^{55}\end{array}$ & $\begin{array}{l}\text { Heterogeneous, including dementia } \\
\text { \& ataxia; psychiatric \& visual Sx } \\
\text { are less common; sleep distur- } \\
\text { bances at early stages of disease } \\
\text { are often not investigated }\end{array}$ & $\begin{array}{l}\text { Gliosis \& neuronal loss involving medial dorsal } \\
\text { \& anterior ventral thalamic nuclei \& inferior } \\
\text { olive; spongiform degeneration is minimal \& } \\
\text { focal }\end{array}$ \\
\hline VPSPr & $\begin{array}{l}\text { Median } 70,,^{79} \\
\text { SD } 9,^{79} \text { range } \\
48-87^{55}\end{array}$ & $\begin{array}{l}\text { Median } 24,{ }^{79} \mathrm{SD} 10,,^{79} \\
\quad \text { range } 7-73^{55}\end{array}$ & $\begin{array}{l}\text { Psychiatric signs, speech impair- } \\
\text { ment, \& dementia }\end{array}$ & $\begin{array}{l}\text { Spongiform degen w/ different size of vacuoles, } \\
\text { microplaques in cerebellar molecular layer; } \\
\text { round \& loose clusters of coarse PrP gran- } \\
\text { ules in cerebrum }\end{array}$ \\
\hline
\end{tabular}

Degen = degenerative; FFI = fatal familial insomnia; FI = fatal insomnia; GSS = Gerstmann-Schäussler-Scheinker syndrome; M/V = methionine/valine heterozygosity; $\mathrm{Sx}=$ symptoms; $\mathrm{VPSPr}=$ variably protease-sensitive prionopathy.

* Dura mater graft-associated CJD.

$\dagger$ Unicentric round plaque with a dense eosinophilic core and radiating spicules.

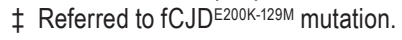

$\S$ Referred to GSS ${ }^{\mathrm{P} 102 \mathrm{~L}-129 \mathrm{M}}$ mutation.

ons via the surgical instruments, as neural tissue presents the highest infectious burden of the disease. ${ }^{8}$

Highly sensitive and specific diagnostic tests using cerebrospinal fluid and/or nasal brushings are becoming available at the National Prion Disease Pathology Surveillance Center (Cleveland, Ohio) ${ }^{70,71}$ Nevertheless, a definitive antemortem diagnosis of prion disease can only be made by tissue biopsy. The current difficulties in identifying prion-infected living patients constitute one of several challenges faced by institutions when determining whether specific prion decontamination measures should be taken during a neurosurgical procedure. In addition, the inability to identify patients who have been recently infected with the prion agent complicates responses to inadvertent exposures of surgical patients to potentially prion-contaminated instruments. This issue may arise when a patient who previously underwent a neurosurgical procedure receives a postoperative diagnosis of prion disease. Assessing the risk to those potentially exposed to contaminated instruments and making decisions related to informing such patients and preventing further exposures to the instruments can be difficult, time consuming, and costly. Fortunately, only a very small fraction of the total number of prion disease cases reported to date resulted from iatrogenic transmission following neurological surgery with contaminated instruments, although complete case ascertainment is very difficult.12,17 Preventing iatrogenic transmission of prions remains important primarily because prion diseases are invariably fatal. The social costs of iatrogenic transmission must also be considered; such costs include loss of public trust in medical personnel and institutions, investigative costs, and potential lawsuits.

This review seeks to provide an update on the existing information on the transmission of human prion diseases. A general background of the historical, epidemiological, pathobiological, and clinical aspects of the prion diseases 
is first provided, followed by descriptions of previous incidents and corresponding recommendations by the Centers for Disease Control and Prevention (CDC) and World Health Organization (WHO). This review is intended to disseminate information on how iatrogenic transmission of prion disease can be avoided in the hospital setting.

\section{Human Prion Diseases: Historical Perspective}

Human prion disease first came to the attention of the global scientific community during the 1950s when D. Carleton Gajdusek, a US physician and medical researcher, was called to investigate a "strange, encephalitis-like disease" occurring predominately among women and children of the Fore linguistic region of Papua New Guinea. ${ }^{33,59}$ Oral history provided by the inhabitants of the region indicated that the first appearance of the disease may have occurred around 1910. ${ }^{.2}$ At the time of Gajdusek's initial report, a full epidemic had been recognized, with more than 1000 cases identified in the first 10 months of the opening of a native hospital for the treatment and study of the disease. ${ }^{34}$ Kuru, as the disease was known among the Fore, is a word used to designate the trembling associated with fear or cold. Gajdusek and his colleague V. Zigas, a medical officer in the Fore tribe region of New Guinea, lived among the Fore and investigated this major medical problem.

In describing kuru to the (then) director of the National Institutes of Health (NIH), Gajdusek wrote:

Emotional instability is certain; a tendency to excessive hilarity, etc. is certain. The "mask-like" facies is rather a fixed facies - but not "mask-like"... The entire postural tremor situation is most complex. It is not a true cerebellar, nor a true parkinsonism tremor. It is, rather, a tremor and other types of involuntary movements which are very irregular and difficult to describe.... Toes are constantly gripping and searching when a patient tries to stand unaided-or, if more advanced, even when supported. Sudden loss of antigravity postural support, given passively by an examiner to head or upper extremities, suddenly sets off repetitive, irregular tremors or a choreiform pattern of movement. Rigidity is minimal, if at all present. It appears late. Instead, there is an increased tone to the muscles that are associated with attempts at maintaining posture and preventing the antigravity tremors which fight the slightest instability of standing, sitting, lying, head posture, etc. and which initiate as a startle response. If well and firmly supported passively, even in late cases, this "intermittent rigidity" subsides to complete relaxation. ${ }^{56}$

Gajdusek later noted the similarity of kuru to "heterofamilial degenerative disorders of the central nervous system," ${ }^{34}$ whereas Igor Klatzo, neuropathologist at NIH, compared kuru to Creutzfeldt-Jakob disease (CJD), the latter being documented only 20 times and never observed in children. ${ }^{59}$ In 1957, Klatzo wrote: "[kuru] seems to be definitely a new condition without anything similar described in the literature. The closest condition that I can think of is that described by Jacob and Creutzfeldt."' Klatzo detected the vacuoles and the amyloidal kuru plaques in the brain of individuals with kuru, and, in 1959, he published a paper describing kuru's histopathological features and the similarities between kuru and CJD. ${ }^{51}$ In 1966, Gajdusek, Gibbs, and Alpers experimentally transmitted kuru to chimpanzees, confirming that kuru was an infectious condition..$^{32,43}$

Two years later, CJD was shown to be transmissible. Gibbs and Gajdusek proposed the name of "subacute spongiform encephalopathy" for the entire class of scrapie-like diseases. ${ }^{42,43}$ The pathogenesis of the transmissible spongiform encephalopathies, however, remained a mystery, the solution to which would have an enormous impact on medicine.

\section{Kuru and Cannabalism}

Epidemiological and clinical research conducted by Zigas and Gajdusek revealed a complicated picture. According to their 1959 report, ${ }^{34}$ kuru had the following properties. 1) It was responsible for the death of approximately $1 \%$ of the population per year (up to $50 \%$ in certain areas). 2) It mainly affected adult females, with up to $25 \%$ of cases involving children. 3) It was restricted to the Fore people and some of their tribal neighbors. 4) Its histopathological hallmarks included neurological degeneration, myelin degeneration, astroglial and microglial proliferation, most predominately in the cerebellum and extrapyramidal system. 5) Cases of kuru had no identifiable relationship with cases of (presumably viral) infectious meningoencephalitis or with any toxic ingestion.

Gajdusek himself postulated a genetic predisposition to the spread of kuru; however, little evidence could be found to support such a hypothesis. Currently, however, we understand that heterozygosity at codon 129 of the prion protein $(\mathrm{PrP})$ gene $(P R N P)$ is protective (see below).

Remarkably, the kuru-affected people of Papua New Guinea were unique in their practice of "endocannabalism." As Alpers describes, the people of the Fore region believed the "mortuary practice of consumption of the dead and incorporation of the body of the dead person into the bodies of living relatives, thus [helped] to free the spirit of the dead." In fact, the whole body of the deceased kin was eaten by female relatives and children of both sexes. Adult males, which included boys above age 7 , rarely took part in this practice. 61,87 The sex and age distribution of the kuru epidemic could thus be satisfactorily explained by the mortuary practices of the affected people. In fact, after the abandonment of the practice by the early 1960s (following the urging of the Australian administration), there was a sharp decline in cases that was characterized by the long incubation period of the disease. ${ }^{4}$

The ensuing decades of clinical and basic research revealed the etiologic agent of kuru to be a small, self-aggregating protein unlike any infectious entity previously identified in biology. The agent, now known as "prion," introduced to the scientific community principles of molecular catalytic activity that would influence the fields of molecular biology, genetics, virology, amyloidology, and aging. Such was the impact of the elucidation of the pathophysiology of kuru that D. Carleton Gajdusek was awarded the Nobel Prize in Physiology or Medicine in 1976 for his work on the transmission of the disease. Stanley Prusiner, whose work is described below, also received the Nobel Prize in 1997 for his work on the molecular identification and characterization of the prion protein. The detailed findings of the investigation into kuru and 
the discovery and development of the concept of transmissible prion proteins were summarized by Dr. Gajdusck and Dr. Prusiner, respectively, in Fields' Fundamentals of Virology, published in $1996 .{ }^{31,78}$

\section{Human Prion Diseases in the 21st Century}

The term "prion" was coined in 1982 by Stanley B. Prusiner to describe "proteinaceous infectious" particles responsible for scrapie in goats and sheep. ${ }^{77}$ Since their initial elucidation, much work has been done to understand and categorize these fatal neurodegenerative conditions. Prion diseases have different etiologies: they can arise sporadically, be genetically inherited, or acquired by infection.

The normal or cellular $\operatorname{PrP}\left(\operatorname{PrP}^{\mathrm{C}}\right)$ is a glycosylphosphatidylinositol-anchored membrane glycoprotein that is largely expressed in neural and nonneural tissues and found primarily on the cell surface-plasma membrane of the central nervous system. $\operatorname{PrP}^{\mathrm{C}}$ is encoded by the $P R N P$ gene on chromosome 20 and comprises 209 amino acids that fold to produce an $\alpha$-helix-rich conformation that is soluble in buffers containing detergent and readily digested by proteases (e.g., by the proteinase K). ${ }^{48,77,80}$ The function of $\mathrm{PrPC}^{\mathrm{C}}$ is largely unknown. ${ }^{61,86}$

The abnormal or pathological form of $\mathrm{PrP}\left(\mathrm{PrP}^{\mathrm{Sc}}\right)$ displays a predominantly $\beta$-sheet conformation with a $\mathrm{C}$ terminal region that is partially resistant to proteolytic degradation. ${ }^{7,22,35}$ The conformational conversion of $\operatorname{PrP}^{\mathrm{C}}$ to $\mathrm{PrP}^{\mathrm{Sc}}$ seems to occur in a reaction whereby $\alpha$-helical structures of $\mathrm{PrP}^{\mathrm{C}}$ refold into a $\beta$-sheets structure using a preexisting $\mathrm{PrP}^{\mathrm{Sc}}$ as a template. ${ }^{1,27,40,49}$ Although the accumulation of the proteinase $\mathrm{K}$-resistant $\mathrm{PrP}^{\mathrm{Sc}}$, a gold standard marker for prion disease, may not always be observed with standard detection procedures in a few human prion diseases, a central pathogenic event is the accumulation of $\mathrm{PrP}^{\mathrm{Sc}}$ that is partially resistant to proteases ${ }^{84}$

Polymorphism at codon 129 of the PRNP gene, encoding for either methionine (M) or valine (V), has been demonstrated to play a role in host susceptibility to phenotypic expression of sporadic, familial, and acquired or iatrogenic forms of prion disease. ${ }^{23,25,74}$ Codon $129 \mathrm{M} / \mathrm{V}$ heterozygosity seems to be protective against human prion diseases, ${ }^{93}$ and several studies have indicated a prominence of homozygosity for either methionine $(129 \mathrm{M} / \mathrm{M})$ or valine (129 $\mathrm{V} / \mathrm{V}$ ) in individuals with prion disease. ${ }^{23,52,63}$ Although the biophysical interplay between codon 129 and $\mathrm{PrP}^{\mathrm{Sc}}$ conversion is incompletely understood, the epidemiological association is of considerable clinical predictive value.

There is a great deal of phenotypic heterogeneity in the prion diseases. The clinicopathological phenotype in CJD and other prion diseases is also influenced by the different types of the pathological PrPsc, identified as Type 1 and Type $2.66,72,75$

\section{Creutzfeldt-Jakob Disease}

The most common human prion disease is CreutzfeldtJakob disease (CJD), with an estimated incidence of 1-1.5 cases per million people per year. ${ }^{8}$ Approximately $85 \%$ of all CJD cases are sporadic (sCJD) and considered to arise from somatic alteration in $\mathrm{PrP}^{\mathrm{C}} .{ }^{30,35}$ A modern classifica- tion of sCJD into 5 distinct subtypes combines 2 types of $\mathrm{PrP}^{\mathrm{Sc}}$ (Type 1 and Type 2) and 3 possible genotypes at codon 129 (129 M/M, $129 \mathrm{M} / \mathrm{V}$, and $129 \mathrm{~V} / \mathrm{V})$. Each subtype of SCJD is characterized by a distinct clinical and histopathological phenotype. ${ }^{19,74}$ Genetic or familial CJD (fCJD) represents $5 \%-15 \%$ of all CJD cases ${ }^{39}$ and is associated with several pathogenic mutations in the PRNP gene. Patients with fCJD are usually younger than those with SCJD. Clinically, fCJD presents with rapidly progressive neurological and neuropsychiatric dysfunction, including dementia, visual abnormalities, muscle incoordination and myoclonus, and gait and speech abnormalities (Table 1). The rates of progression and symptoms at onset vary depending on the SCJD subtype. In about 85\%-90\% of cases, however, patients deteriorate rapidly, with death occurring within 12 months of the onset of illness. ${ }^{8}$ Variant CJD (vCJD) was initially reported in 1996 as a small case series of CJD-like illnesses in the United Kingdom that was epidemiologically linked to an outbreak of bovine spongiform encephalopathy (BSE). Affected patients exhibited early-onset disease (median age 28 years) with prominent behavioral changes at clinical presentation followed by neurological abnormalities, dementia, and myoclonus later in the course of the illness. ${ }^{91}$ Epidemiological and laboratory studies indicated that the same prion agent was responsible for BSE and vCJD. ${ }^{46,64}$ Iatrogenic transmission of VCJD has been linked to blood products (3 clinical cases and 2 subclinical cases) $)^{5,82}$ rendering iatrogenic transmission of prion diseases a greater potential problem.

\section{Fatal Insomnia}

Sporadic fatal insomnia (sFI) and fatal familial insomnia (FFI) are characterized by bilateral symmetric degeneration of the thalamus with marked gliosis and absence of minimal spongiform degeneration..$^{38}$ Patients predominantly exhibit severe sleep disturbances, often with intractable insomnia, and autonomic dysfunction, characterized by hyperhidrosis, hyperthermia, tachycardia, and hypertension. ${ }^{39}$ It is most commonly associated with PRNP gene mutation at codon 178 (FFI), but sporadic cases have been identified lacking such mutation (sFI). ${ }^{39,73}$

\section{Kuru}

The clinical picture of kuru, as described above, is considerably distinct from that of classic CJD. Cases occurring 50 years after participation in ritual cannibalism have been reported ${ }^{24}$ suggesting that measuring the full risk of person-to-person transmissions of prion disease can be challenging due to possibly decades-long incubation periods.

\section{Gerstmann-Sträussler-Scheinker Syndrome}

Gerstmann-Sträussler-Scheinker syndrome (GSS) is a slowly progressive hereditary cerebellar syndrome associated with PRNP point mutations at different codons ${ }^{60}$ The incidence of GSS is estimated at approximately 1-10 cases per 100 million people per year. ${ }^{59}$ Typically reported neurological symptoms include cerebellar ataxia, gait abnormalities, dementia, dysarthria, ocular dysmetria, and hyporeflexia or areflexia in the lower extremities. As with 
sCJD, however, the different mutations confer different clinical and histopathological phenotypes.

\section{Variably Protease-Sensitive Prionopathy}

Variably protease-sensitive prionopathy (VPSPr) is a recently identified prion disease affecting an estimated 2-3 people per 100 million per year. ${ }^{36,94}$ Clinical onset is characterized by psychosis, mood changes, speech impairment, and dementia, whereas progressive motor dysfunction is usually observed at later stages of the disease. About $30 \%$ of the affected individuals have a family history of dementia. The median age of disease onset, and the disease duration, is 70 years and 2 years, respectively. In VPSPr, disease prevalence in association with the 3 codon 129 genotypes of the $P R N P$ gene (i.e., $\mathrm{M} / \mathrm{M}, \mathrm{M} / \mathrm{V}$, and $\mathrm{V} / \mathrm{V})$ is different from that of sCJD, suggesting a different role of codon 129 as a risk factor in the 2 conditions (VPSPr: $62 \% \mathrm{~V} / \mathrm{V}, 26 \% \mathrm{M} / \mathrm{V}$, and 12\% M/M; sCJD: $19 \%$ $\mathrm{V} / \mathrm{V}, 11 \% \mathrm{M} / \mathrm{V}$, and $70 \% \mathrm{M} / \mathrm{M}){ }^{79}$ Other features of VPSPr are different sensitivity of $\mathrm{PrP}^{\mathrm{Sc}}$ to proteolytic digestion with proteinase K (hence "variably protease-sensitive"), and poor transmission of the disease to transgenic mice expressing the human $\operatorname{PrP}^{\mathrm{C}} .69$

\section{latrogenic CJD: Historical Context}

Iatrogenic CJD (iCJD) refers to the transmission of prions via inadvertent medical exposure. The first documented case of iCJD occurred via infected corneal transplant, and was described by Duffy in $1974 . .^{28}$ Three earlier iatrogenic prion transmissions by surgical instruments were suggested by examination of case notes of CJD cases described in a report by Nevins et al. in $1960 .{ }^{67,90} \mathrm{~A}$ fourth case of iatrogenic CJD attributed to a contaminated neurosurgical instrument was described by el Hachimi and colleagues in 1977; the case involved a 46-year-old man who had undergone cranial surgery in the same department 3 days after a cortical biopsy had confirmed CJD in a 59-year-old woman..$^{29}$ In 1977, Christoph Bernoulli realized that a cortical electrode probe used in an elderly patient had transmitted CJD to 2 younger patients undergoing subsequent epilepsy surgery. ${ }^{10}$ Subsequent reports demonstrated the transmission of CJD to the frontal lobes of chimpanzees with the same electrodes, even after scrupulous attempts to clean them. ${ }^{42}$

More than 492 (personal communication to L.B.S., 2015) cases of iCJD have been identified worldwide (Table 2). ${ }^{15}$ The majority of such cases resulted from the administration of prion-contaminated human growth hormone (hGH) and cadaveric dura mater graft. Other sources of iatrogenic transmission of the disease are contaminated blood, corneas, and neurosurgical instrumentation. Because of the latter risk, Drs. Paul Brown and Michael Farrell recently proposed routine use of prion diagnostic testing on all patients admitted with symptoms of either dementia or cerebellar disease and containment of infectivity commensurate with the degree of potential risk. ${ }^{16}$

\section{Cadaveric Dura Mater Transplantation}

The transmission of CJD by transplantation of commercially distributed cadaveric dura mater (dCJD) was
TABLE 2. Worldwide incidence of iatrogenic transmission of prion infectivity*

\begin{tabular}{|c|c|c|c|}
\hline $\begin{array}{l}\text { Procedure \& Means } \\
\text { of Transmission }\end{array}$ & $\begin{array}{l}\text { No. of } \\
\text { Cases }\end{array}$ & $\begin{array}{l}\text { Mean Incubation } \\
\text { Period in Yrs } \\
\text { (range) }\end{array}$ & $\begin{array}{c}\text { Predominant } \\
\text { Clinical Findings } †\end{array}$ \\
\hline \multicolumn{4}{|l|}{ Surgical procedure } \\
\hline Dura mater graft & 238 & $12 \ddagger(1.3-30)$ & $\begin{array}{l}\text { Cerebellar, visual, } \\
\text { dementia }\end{array}$ \\
\hline $\begin{array}{l}\text { Surgical instru- } \\
\text { ment }\end{array}$ & $4 \S$ & $1.6(1.4-2.2)$ & $\begin{array}{l}\text { Visual, dementia, } \\
\text { cerebellar }\end{array}$ \\
\hline Corneal transplant & 2 & $15.75(1.5-30)$ & Dementia, cerebellar \\
\hline $\begin{array}{l}\text { EEG depth elec- } \\
\text { trode }\end{array}$ & 2 & $1.5(1.3-1.7)$ & Dementia, cerebellar \\
\hline \multicolumn{4}{|l|}{ Medical procedure } \\
\hline hGH treatment & 238 & $17 \rrbracket(5-42)$ & Cerebellar \\
\hline $\begin{array}{c}\text { Gonadotropin } \\
\text { treatment }\end{array}$ & 4 & $13.5(12-16)$ & Cerebellar \\
\hline Blood transfusion & $3^{* *}$ & $7.53(6.5-8.3)$ & $\begin{array}{l}\text { Psychiatric, sensory, } \\
\text { dementia, cer- } \\
\text { ebellar }\end{array}$ \\
\hline
\end{tabular}

\footnotetext{
* Data adapted and updated from Brown et al.. ${ }^{15}$ Will \& Matthews, ${ }^{90}$ and personal communication to L.B.S., 2015.

$\dagger$ In order of decreasing frequency.

¥ Based on the 228 cases reported by Brown et al. ${ }^{15}$

$\S$ Excludes 2 CJD decedents who were homozygous for methionine encoding at codon 129 of their PRNP gene, a neurosurgeon and a patient who had undergone a neurosurgical procedure 14 years before onset, whose atypical neuropathology indicated iatrogenic disease.

II Based on the 226 cases reported by Brown et al. ${ }^{15}$

** Excludes 2 VCJD-infected decedents who died from causes other than prion disease and had received either non-leukoreduced blood cells or Factor VIII from donors who subsequently developed VCJD.
}

first recognized in $1987 .{ }^{21}$ Since then, at least $238 \mathrm{dCJD}$ cases (personal communication to L.B.S., 2015) have been identified worldwide, with over $60 \%$ occurring in Japan, reflecting primarily the frequent use of Lyodura. Lyodura was produced by the German manufacturer B. Braun Melsungen AG and was the major source of the outbreak. In 1987, the manufacturer reported that it changed its procedures to reduce the risk of prion contamination of its product. The mean incubation period for exposed dCJD patients has been estimated to be 12 years (range 1.2-30 years), although cases with even longer incubation periods are likely to occur. The predominant symptomatology has been atypical (slowly progressive and without characteristic electroencephalography [EEG] findings). ${ }^{15,53}$ In Japan, 2 groups of dCJD with distinct phenotypes and molecular features have been recently described. ${ }^{53}$

\section{Human Growth Hormone Administration}

The treatment of short stature with pituitary-derived human growth hormone (hGH) began in the 1950s and has been associated with more than 238 iCJD cases to date $^{15,20}$ (personal communication to L.B.S., 2015). The majority of hGH-CJD cases have occurred in France, specifically among patients who received hGH treatment between December 1983 and July 1985 (119 cases in 1170 
exposed patients). In the UK and the US, the numbers of cases are fewer (75 and 31, respectively). Except for 1 case of CJD associated with commercially derived hGH, 30 of the 31 patients in the US cases received hGH treatment through the government-supported National Hormone and Pituitary Program. In this program, no CJD cases have been identified among recipients who began their hormone treatment after 1977, the year when a highly selective column chromatography step was included in the purification protocol..$^{15}$ The mean incubation time for hGH-CJD patients worldwide has been estimated to be 17 years (range 5-42 years), and the associated clinical picture is predominantly cerebellar, with dementia occurring late in the development should it appear.

\section{Blood Transfusion}

The first convincing evidence for blood transfusion transmission of a human prion disease was reported for vCJD in 2003. As indicated in Table 2, 5 cases of vCJD infection, including 3 involving patients who became ill with VCJD, have been documented among recipients of blood products from donors who subsequently developed vCJD. (Table 2). ${ }^{26,50,76}$

\section{Other Sources}

Although the vast majority of iCJD cases have occurred because of contaminated hGH or dura mater graft, other identified sources include corneal transplantation ${ }^{65}$ and contaminated stereotactic EEG depth electrodes. ${ }^{14,44,46}$ In four cases, patients underwent corneal transplantation or EEG with grafts from or instruments previously used on patients in patients subsequently discovered to have died of confirmed CJD.. The latency period for corneal transplant cases ranged from 18 months to 30 years, whereas the latency periods for the cases ascribed to the contaminated EEG depth electrodes were 16 months and 20 months..$^{13,45}$

\section{Transmission of Human Prions by Neurosurgical Instruments}

Iatrogenic transmission of CJD via neurosurgical instrumentation is a worrisome, although rare, phenomenon. Four cases have been documented in the literature, with three having occurred in the UK and one in France during the 1950s. ${ }^{29,90}$ Exposed patients presented back to the hospital with onset of CJD between 1.4 and 2.2 years after their surgery. Although there have been no documented cases in the US, the unusual pathology of one CJD case in a US neurosurgeon has been reported to suggest iatrogenic rather than sporadic disease.$^{54}$ In addition, several potential exposures have been described. ${ }^{9,85}$

In the 15-year period (1998-2012), 19 incidents of suspected CJD exposure via contaminated surgical instruments in the US were reported to the CDC. Two cases involved ophthalmological procedures, whereas 17 involved intracranial neurological operations that were performed as a diagnostic workup in most of the cases. Operative personnel were not aware that their patient was infected with the CJD agent, so no recommended CJD-related protocols for instrument tracking/decontamination were followed. The contaminated instruments were cycled through the normal decontamination process and reused on subsequent patients. Several hospitals reported having multiple neurosurgical instrument sets, and in most of these hospitals (11 of 19) the originally contaminated set could not be identified.

The potential nosocomial exposure to the CJD agent raises several concerns. Most important is the prevention of further exposure of patients to CJD. This requires identification of potentially contaminated instruments and their proper quarantine and sterilization. As demonstrated by these cases, instrument tracking can be very difficult when there are multiple instrument sets and when a large amount of time has passed since the initial neurosurgery. In some of the above-mentioned hospitals, the entire collection of sets had to be quarantined and decontaminated. ${ }^{9}$ Instruments used for neurosurgery in patients with dementia or cerebellar signs for whom there is not convincing evidence against a prion disease should be decontaminated using the sterilization protocols developed by WHO.

A second important consideration is patient notification. The hospital should try to identify the patients potentially exposed to the index instruments (another epidemiological obstacle) and decide if anyone, appropriately, should be notified. In this regard, several factors should be taken into account. ${ }^{9}$

\section{Risk Assessment and Mitigation}

Given the difficulty of tracking instruments and connecting them to patients, it is crucial to identify patients who have, or are at risk for having, a prion disease before they undergo surgical procedures. Successful implementation of the appropriate precautions can effectively eliminate the risk of subsequent iatrogenic events. Suggestions for mitigation are provided in the WHO Infection Control Guidelines for the Transmissible Spongiform Encephalopathies. ${ }^{88}$

According to these guidelines, prior to the operation, efforts should be made to minimize the extent of contamination. The WHO specifically suggests that all staff directly involved in the procedure or the reprocessing or disposal of the contaminated items be made aware of recommended precautions; operative and relevant staff must be given enough time to obtain suitable instrumentation and equipment; specific protocols are followed; and staff is appropriately trained for these protocols. It is also suggested that the procedure in question be scheduled for the end of the day (i.e., as the last case) to ensure adequate time for decontamination. These procedures may have a visible effect on the surgical instrument to which the procedure is applied..$^{18}$

The WHO also lists basic protective measures to be taken within the operating room: ${ }^{88} 1$ ) involve a minimum number of health care personnel in the operating room; 2) use single-use equipment whenever possible; 3 ) cover all nondisposable equipment (Fig. 1); 4) maintain a "one-way flow" of instruments; 5) dispose of single-use items via incineration when possible; and 6) clean all work surface areas according to guidelines.

\section{Prion Protein Resilience and Decontamination}

The most commonly used methods for disinfection and sterilization may not be adequate to remove all prion in- 


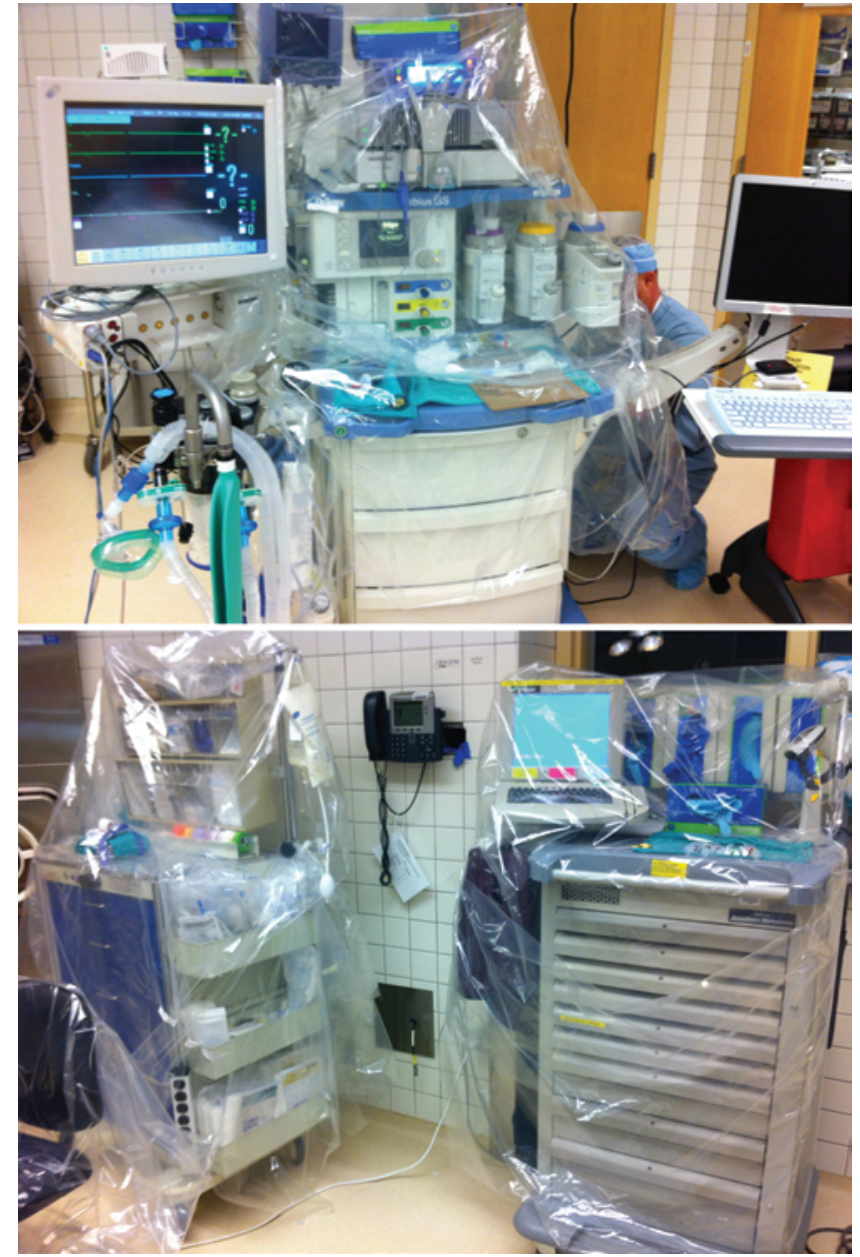

FIG. 1. Photographs showing the method used for protecting nondisposable operating room equipment. To minimize surface exposure to prion-related contaminants, all nondisposable instrumentation should be covered in a disposable protective material. Following the operation, these disposable items should be incinerated.

fectivity. Chemical disinfectants (e.g., alcohol, ammonia, formalin, hydrochloric acid, and phenolics) and common thermal or ionizing treatments (boiling, dry heating, and ultraviolet light or microwave exposure) do not effectively denature the prion particles. Prion stability is, in fact, enhanced by drying or by fixation in alcohol, formalin, and glutaraldehyde..$^{57}$ Therefore, traditional means of instrument decontamination may not suffice for prion-infected utensils. The recommended prion decontamination protocols for reusable surgical instruments and surfaces recommended by WHO and CDC have been published and are readily available on CDC's website (http://www.cdc.gov/ prions/cjd/infection-control.html). ${ }^{11}$

\section{Conclusions}

Iatrogenic forms of CJD represent a unique challenge to neurosurgeons. Although their incidence is rare, and the likelihood of encountering them in surgical practice is low, a missed diagnosis of prion disease in a neurosurgical patient can severely and negatively impact patients and associated hospitals. It is therefore important to remain vigilant during preoperative workup, especially when the preprocedural differential diagnosis could include the suspicion of a prion disease. Although intensive, the recommended precautions can reduce the potential risk of nosocomial prion infections and minimize the negative consequences.

\section{Acknowledgments}

We thank Pierluigi Gambetti, MD (Department of Pathology, Case Western Reserve University), and Lynne M. Sehulster, PhD, M(ASCP) (National Center for Emerging and Zoonotic Diseases, Centers for Disease Control and Prevention), for helpful comments.

\section{References}

1. Acquatella-Tran Van Ba I, Imberdis T, Perrier V: From prion diseases to prion-like propagation mechanisms of neurodegenerative diseases. Int J Cell Biol 2013:975832, 2013

2. Aguzzi A, Sigurdson C, Heikenwaelder M: Molecular mechanisms of prion pathogenesis. Annu Rev Pathol 3:11-40, 2008

3. Alcalde-Cabero E, Almazan-Isla J, Brandel JP, Breithaupt M, Catarino J, Collins S, et al: Health professions and risk of sporadic Creutzfeldt-Jakob disease, 1965 to 2010. Euro Surveill 17:20144, 2012

4. Alpers MP: Review. The epidemiology of kuru: monitoring the epidemic from its peak to its end. Philos Trans R Soc Lond B Biol Sci 363:3707-3713, 2008

5. Andréoletti O, Litaise C, Simmons H, Corbière F, Lugan S, Costes P, et al: Highly efficient prion transmission by blood transfusion. PLoS Pathog 8:e1002782, 2012

6. Asher DM: Kuru: memories of the NIH years. Philos Trans R Soc Lond B Biol Sci 363:3618-3625, 2008

7. Baldwin MA, James TL, Cohen FE, Prusiner SB: The threedimensional structure of prion protein: implications for prion disease. Biochem Soc Trans 26:481-486, 1998

8. Belay ED: Transmissible spongiform encephalopathies in humans. Annu Rev Microbiol 53:283-314, 1999

9. Belay ED, Blase J, Sehulster LM, Maddox RA, Schonberger LB: Management of neurosurgical instruments and patients exposed to Creutzfeldt-Jakob disease. Infect Control Hosp Epidemiol 34:1272-1280, 2013

10. Bernoulli C, Siegfried J, Baumgartner G, Regli F, Rabinowicz T, Gajdusek DC, et al: Danger of accidental person-toperson transmission of Creutzfeldt-Jakob disease by surgery. Lancet 1:478-479, 1977

11. Bradford BM, Piccardo P, Ironside JW, Mabbott NA: Human prion diseases and the risk of their transmission during anatomical dissection. Clin Anat 27:821-832, 2014

12. Brown P: Environmental causes of human spongiform encephalopathy, in Baker HF, Ridley RM (eds): Prion Diseases. Totowa, NJ: Humana Press, 1996

13. Brown P: Environmentally acquired transmissible spongiform encephalopathy, in Zhou W, Gambetti P (eds): Prions and Diseases. New York: Springer, 2013, Vol 2, pp 73-88

14. Brown P, Brandel JP, Preece M, Sato T: Iatrogenic Creutzfeldt-Jakob disease: the waning of an era. Neurology 67:389-393, 2006 [Erratum in Neurology 67:1528, 2006]

15. Brown P, Brandel JP, Sato T, Nakamura Y, MacKenzie J, Will $\mathrm{RG}$, et al: Iatrogenic Creutzfeldt-Jakob disease, final assessment. Emerg Infect Dis 18:901-907, 2012

16. Brown P, Farrell M: A practical approach to avoiding iatrogenic Creutzfeldt-Jakob disease (CJD) from invasive instruments. Infect Control Hosp Epidemiol 36:844-848, 2015

17. Brown P, Preece M, Brandel JP, Sato T, McShane L, Zerr I, et al: Iatrogenic Creutzfeldt-Jakob disease at the millennium. Neurology 55:1075-1081, 2000

18. Brown SA, Merritt K, Woods TO, Busick DN: Effects on instruments of the World Health Organization-recommended 
protocols for decontamination after possible exposure to transmissible spongiform encephalopathy-contaminated tissue. J Biomed Mater Res B Appl Biomater 72:186-190, 2005

19. Cali I, Castellani R, Yuan J, Al-Shekhlee A, Cohen ML, Xiao $\mathrm{X}$, et al: Classification of sporadic Creutzfeldt-Jakob disease revisited. Brain 129:2266-2277, 2006

20. Cali I, Miller CJ, Parisi JE, Geschwind MD, Gambetti P, Schonberger LB: Distinct pathological phenotypes of Creutzfeldt-Jakob disease in recipients of prion-contaminated growth hormone. Acta Neuropathol Commun 3:37, 2015

21. Centers for Disease Control: Rapidly progressive dementia in a patient who received a cadaveric dura mater graft. MMWR Morb Mortal Wkly Rep 36:49-50, 55, 1987

22. Cobb NJ, Apetri AC, Surewicz WK: Prion protein amyloid formation under native-like conditions involves refolding of the C-terminal alpha-helical domain. J Biol Chem 283:34704-34711, 2008

23. Collinge J, Palmer MS, Dryden AJ: Genetic predisposition to iatrogenic Creutzfeldt-Jakob disease. Lancet 337:1441-1442, 1991

24. Collinge J, Whitfield J, McKintosh E, Beck J, Mead S, Thomas DJ, et al: Kuru in the 21st century-an acquired human prion disease with very long incubation periods. Lancet 367:2068-2074, 2006

25. Deslys JP, Marcé D, Dormont D: Similar genetic susceptibility in iatrogenic and sporadic Creutzfeldt-Jakob disease. J Gen Virol 75:23-27, 1994

26. Diack AB, Head MW, McCutcheon S, Boyle A, Knight R, Ironside JW, et al: Variant CJD. 18 years of research and surveillance. Prion 8:286-295, 2014

27. Diaz-Espinoza R, Soto C: High-resolution structure of infectious prion protein: the final frontier. Nat Struct Mol Biol 19:370-377, 2012

28. Duffy P, Wolf J, Collins G, DeVoe AG, Streeten B, Cowen D: Letter: Possible person-to-person transmission of CreutzfeldtJakob disease. N Engl J Med 290:692-693, 1974

29. el Hachimi KH, Chaunu MP, Cervenakova L, Brown P, Foncin JF: Putative neurosurgical transmission of Creutzfeldt-Jakob disease with analysis of donor and recipient: agent strains. C R Acad Sci III 320:319-328, 1997

30. Elmallah MI, Borgmeyer U, Betzel C, Redecke L: Impact of methionine oxidation as an initial event on the pathway of human prion protein conversion. Prion 7:404-411, 2013

31. Gajdusek D: Infectious amyloids: subacute spongiform encephalopathies as transmissible cerebral amyloidoses, in Fields B (ed): Fundamental Virology, ed 3. Philadelphia: Lippincott-Raven, 1996, pp 2851-2901

32. Gajdusek DC, Gibbs CJ, Alpers M: Experimental transmission of a kuru-like syndrome to chimpanzees. Nature 209:794-796, 1966

33. Gajdusek DC, Zigas V: Degenerative disease of the central nervous system in New Guinea; the endemic occurrence of kuru in the native population. N Engl J Med 257:974-978, 1957

34. Gajdusek DC, Zigas V: Kuru; clinical, pathological and epidemiological study of an acute progressive degenerative disease of the central nervous system among natives of the Eastern Highlands of New Guinea. Am J Med 26:442-469, 1959

35. Gambetti P, Cali I, Notari S, Kong Q, Zou WQ, Surewicz WK: Molecular biology and pathology of prion strains in sporadic human prion diseases. Acta Neuropathol 121:7990,2011

36. Gambetti P, Dong Z, Yuan J, Xiao X, Zheng M, Alshekhlee A, et al: A novel human disease with abnormal prion protein sensitive to protease. Ann Neurol 63:697-708, 2008

37. Gambetti P, Kong Q, Zou W, Parchi P, Chen SG: Sporadic and familial CJD: classification and characterisation. $\mathbf{B r}$ Med Bull 66:213-239, 2003
38. Gambetti P, Parchi P: Insomnia in prion diseases: sporadic and familial. N Engl J Med 340:1675-1677, 1999

39. Gambetti P, Parchi P, Chen SG: Hereditary Creutzfeldt-Jakob disease and fatal familial insomnia. Clin Lab Med 23:4364, 2003

40. Giachin G, Biljan I, Ilc G, Plavec J, Legname G: Probing early misfolding events in prion protein mutants by NMR spectroscopy. Molecules 18:9451-9476, 2013

41. Gibbs CJ Jr, Asher DM, Kobrine A, Amyx HL, Sulima MP, Gajdusek DC: Transmission of Creutzfeldt-Jakob disease to a chimpanzee by electrodes contaminated during neurosurgery. J Neurol Neurosurg Psychiatry 57:757-758, 1994

42. Gibbs CJ Jr, Gajdusek DC: Infection as the etiology of spongiform encephalopathy (Creutzfeldt-Jakob disease). Science 165:1023-1025, 1969

43. Gibbs CJ Jr, Gajdusek DC, Asher DM, Alpers MP, Beck E, Daniel PM, et al: Creutzfeldt-Jakob disease (spongiform encephalopathy): transmission to the chimpanzee. Science 161:388-389, 1968

44. Hammersmith KM, Cohen EJ, Rapuano CJ, Laibson PR: Creutzfeldt-Jakob disease following corneal transplantation. Cornea 23:406-408, 2004

45. Heckmann JG, Lang CJ, Petruch F, Druschky A, Erb C, Brown P, Neundörfer B: Transmission of Creutzfeldt-Jakob disease via a corneal transplant. J Neurol Neurosurg Psychiatry 63:388-390, 1997

46. Heinemann U, Krasnianski A, Meissner B, Varges D, Kallenberg K, Schulz-Schaeffer WJ, et al: Creutzfeldt-Jakob disease in Germany: a prospective 12-year surveillance. Brain 130:1350-1359, 2007

47. Hill AF, Desbruslais M, Joiner S, Sidle KC, Gowland I, Collinge J, et al: The same prion strain causes vCJD and BSE. Nature 389:448-450, 526, 1997 (Letter)

48. Huang Z, Prusiner SB, Cohen FE: Scrapie prions: a threedimensional model of an infectious fragment. Fold Des 1:13-19, 1996

49. Imran M, Mahmood S: An overview of human prion diseases. Virol J 8:559, 2011

50. Ironside JW: Variant Creutzfeldt-Jakob disease: an update. Folia Neuropathol 50:50-56, 2012

51. Klatzo I, Gajdusek DC, Zigas V: Pathology of kuru. Lab Invest 8:799-847, 1959

52. Kobayashi A, Hizume M, Teruya K, Mohri S, Kitamoto T: Heterozygous inhibition in prion infection: the stone fence model. Prion 3:27-30, 2009

53. Kobayashi A, Matsuura Y, Mohri S, Kitamoto T: Distinct origins of dura mater graft-associated Creutzfeldt-Jakob disease: past and future problems. Acta Neuropathol Commun 2:32, 2014

54. Kobayashi A, Parchi P, Yamada M, Brown P, Saverioni D, Matsuura Y, et al: Transmission properties of atypical Creutzfeldt-Jakob disease: a clue to disease etiology? J Virol 89:3939-3946, 2015

55. Kong Q, Surewicz WK, Petersen RB, Zou WQ, Chen SG, Parchi P, et al: Inherited prion diseases, in Prusiner SB (ed): Prion Biology and Disease. New York: Cold Spring Harbor Laboratory Press, 2004, pp 673-775

56. Lang DJ: Kuru: Early letters and field-notes from the collection of D. Carleton Gajdusek. Isis 73:587-588, 1982

57. Lemmer K, Mielke M, Pauli G, Beekes M: Decontamination of surgical instruments from prion proteins: in vitro studies on the detachment, destabilization and degradation of $\mathrm{PrP}^{\mathrm{Sc}}$ bound to steel surfaces. J Gen Virol 85:3805-3816, 2004

58. Liberski PP: Historical overview of prion diseases: a view from afar. Folia Neuropathol 50:1-12, 2012

59. Liberski PP, Budka H: Gerstmann-Sträussler-Scheinker disease. I. Human diseases. Folia Neuropathol 42 (Suppl B):120-140, 2004

60. Liberski PP, Surewicz WK: Molecular genetics of Gerst- 
mann-Sträussler-Scheinker disease and Creutzfeldt-Jakob disease. Genetics 2:117, 2013

61. Linden R, Martins VR, Prado MAM, Cammarota M, Izquierdo I, Brentani RR: Physiology of the prion protein. Physiol Rev 88:673-728, 2008

62. Lindenbaum S: Cannibalism, kuru and anthropology. Folia Neuropathol 47:138-144, 2009

63. Lloyd S, Mead S, Collinge J: Genetics of prion disease. Top Curr Chem 305:1-22, 2011

64. Mackay GA, Knight RS, Ironside JW: The molecular epidemiology of variant CJD. Int J Mol Epidemiol Genet 2:217-227, 2011

65. Maddox RA, Belay ED, Curns AT, Zou WQ, Nowicki S, Lembach RG, et al: Creutzfeldt-Jakob disease in recipients of corneal transplants. Cornea 27:851-854, 2008

66. Monari L, Chen SG, Brown P, Parchi P, Petersen RB, Mikol J, et al: Fatal familial insomnia and familial CreutzfeldtJakob disease: different prion proteins determined by a DNA polymorphism. Proc Natl Acad Sci U S A 91:2839-2842, 1994

67. Nevin S, McMenemey WH, Behrman S, Jones DP: Subacute spongiform encephalopathy-a subacute form of encephalopathy attributable to vascular dysfunction (spongiform cerebral atrophy). Brain 83:519-564, 1960

68. Noguchi-Shinohara M, Hamaguchi T, Kitamoto T, Sato T, Nakamura Y, Mizusawa H, et al: Clinical features and diagnosis of dura mater graft-associated Creutzfeldt-Jakob disease. Neurology 69:360-367, 2007

69. Notari S, Xiao X, Espinosa JC, Cohen Y, Qing L, AguilarCalvo P, et al: Transmission characteristics of variably protease-sensitive prionopathy. Emerg Infect Dis 20:2006-2014, 2014

70. Orrú CD, Bongianni M, Tonoli G, Ferrari S, Hughson AG, Groveman BR, et al: A test for Creutzfeldt-Jakob disease using nasal brushings. N Engl J Med 371:519-529, 2014

71. Orrú CD, Groveman BR, Hughson AG, Zanusso G, Coulthart MB, Caughey B: Rapid and sensitive RT-QuIC detection of human Creutzfeldt-Jakob disease using cerebrospinal fluid. MBio 6:6, 2015

72. Parchi P, Capellari S, Chen SG, Petersen RB, Gambetti P, Kopp N, et al: Typing prion isoforms. Nature 386:232-234, 1997

73. Parchi P, Capellari S, Chin S, Schwarz HB, Schecter NP, Butts JD, et al: A subtype of sporadic prion disease mimicking fatal familial insomnia. Neurology 52:1757-1763, 1999

74. Parchi P, Giese A, Capellari S, Brown P, Schulz-Schaeffer W, Windl O, et al: Classification of sporadic Creutzfeldt-Jakob disease based on molecular and phenotypic analysis of 300 subjects. Ann Neurol 46:224-233, 1999

75. Parchi P, Zou W, Wang W, Brown P, Capellari S, Ghetti B, et al: Genetic influence on the structural variations of the abnormal prion protein. Proc Natl Acad Sci U S A 97:1016810172, 2000

76. Peden AH, Head MW, Ironside JW: Risk of transmission of Creutzfeldt-Jakob disease by blood transfusion, in Zhou WQ, Gambetti, P (eds): Prions and Diseases. New York: Springer, 2013, Vol 2, pp 121-138

77. Prusiner SB: Novel proteinaceous infectious particles cause scrapie. Science 216:136-144, 1982

78. Prusiner SB: Prions, in Fields BN (ed): Fields Virology, ed 3. Philadelphia: Lippincott-Raven, 1996, pp 2901-2950

79. Puoti G, Bizzi A, Forloni G, Safar JG, Tagliavini F, Gambetti P: Sporadic human prion diseases: molecular insights and diagnosis. Lancet Neurol 11:618-628, 2012

80. Riesner D: Biochemistry and structure of $\mathrm{PrP}^{\mathrm{C}}$ and $\mathrm{PrP}^{\mathrm{Sc}} . \mathbf{B r}$ Med Bull 66:21-33, 2003

81. Sikorska B, Liberski PP: Human prion diseases: from kuru to variant Creutzfeldt-Jakob disease. Subcell Biochem 65:457496, 2012
82. Simpson DA, Masters CL, Ohlrich G, Purdie G, Stuart G, Tannenberg AE: Iatrogenic Creutzfeldt-Jakob disease and its neurosurgical implications. J Clin Neurosci 3:118-123, 1996

83. Spencer MD, Knight RS, Will RG: First hundred cases of variant Creutzfeldt-Jakob disease: retrospective case note review of early psychiatric and neurological features. BMJ 324:1479-1482, 2002

84. Stahl N, Baldwin MA, Burlingame AL, Prusiner SB: Identification of glycoinositol phospholipid linked and truncated forms of the scrapie prion protein. Biochemistry 29:88798884,1990

85. Thomas JG, Chenoweth CE, Sullivan SE: Iatrogenic Creutzfeldt-Jakob disease via surgical instruments. J Clin Neurosci 20:1207-1212, 2013

86. Westergard L, Christensen HM, Harris DA: The cellular prion protein $\left(\mathrm{PrP}^{\mathrm{C}}\right)$ : its physiological function and role in disease. Biochim Biophys Acta 1772:629-644, 2007

87. Whitfield JT, Pako WH, Collinge J, Alpers MP: Mortuary rites of the South Fore and kuru. Philos Trans R Soc Lond B Biol Sci 363:3721-3724, 2008

88. WHO: Infection Control Guidelines for Transmissible Spongiform Encephalopathies. Geneva: World Health Organization, 1999 (http://www.who.int/csr/resources/publications/ bse/whocdscsraph2003.pdf?ua=1) [Accessed May 23, 2016]

89. Will RG, Alpers MP, Dormont D, Schonberger LB, Tateishi $\mathrm{J}$ : Infectious and sporadic prion diseases, in Prusiner SB (ed): Prion Biology and Diseases, ed 2. New York: Cold Spring Harbor Laboratory Press, 2004

90. Will RG, Matthews WB: Evidence for case-to-case transmission of Creutzfeldt-Jakob disease. J Neurol Neurosurg Psychiatry 45:235-238, 1982

91. Will RG, Ward HJ: Clinical features of variant CreutzfeldtJakob disease. Curr Top Microbiol Immunol 284:121-132, 2004

92. Yamada M, Noguchi-Shinohara M, Hamaguchi T, Nozaki I, Kitamoto T, Sato T, et al: Dura mater graft-associated Creutzfeldt-Jakob disease in Japan: clinicopathological and molecular characterization of the two distinct subtypes. Neuropathology 29:609-618, 2009

93. Zimmermann K, Turecek PL, Schwarz HP: Genotyping of the prion protein gene at codon 129. Acta Neuropathol 97:355-358, 1999

94. Zou WQ, Puoti G, Xiao X, Yuan J, Qing L, Cali I, et al: Variably protease-sensitive prionopathy: a new sporadic disease of the prion protein. Ann Neurol 68:162-172, 2010

\section{Disclosures}

The authors report no conflict of interest concerning the materials or methods used in this study or the findings specified in this paper.

\section{Author Contributions}

Conception and design: Bonda. Acquisition of data: Cali, Bonda, Puoti, Cohen, Schonberger. Analysis and interpretation of data: Cali, Schonberger. Drafting the article: Cali, Bonda, Schonberger. Critically revising the article: all authors. Reviewed submitted version of manuscript: all authors. Approved the final version of the manuscript on behalf of all authors: Cali. Administrative/ technical/material support: Cali, Schonberger. Study supervision: Cali.

\section{Correspondence}

Ignazio Cali, Department of Pathology, Case Western Reserve University, 2085 Adelbert Rd., Cleveland, $\mathrm{OH}$ 44106. email: ixc20@case.edu. 